\title{
Detection of Bacterial and Viral Pathogens in Stool Specimens Using Multiplex PCR
}

Jeumsoon Lee, Juwon Kim, Hyunmi Cho, Kijin Oh, Young Uh, and Kap Jun Yoon Department of Laboratory Medicine, Wonju Severance Christian Hospital, Yonsei University Wonju College of Medicine, Wonju, Korea

Corresponding author: Young Uh

Department of Laboratory Medicine, Wonju Severance Christian Hospital, 20 Ilsan-ro, Wonju 26426, Korea Tel: +82-33-741-1592 Fax: +82-33-731-0506 E-mail: u931018@yonsei.ac.kr
Background: The rapid and accurate detection of diarrheal pathogens is essential to prevent the spread of diarrheal diseases. Recently, a multiplex PCR assay was developed to simultaneously detect various bacterial and viral diarrheal pathogens. In this study, we investigated the frequency of detection of various potential pathogens causing diarrhea by using multiplex PCR and compared the results to the results of stool culture tests for bacteria and enzyme immunoassays (EIAs) for rotaviruses and Clostridium difficile toxin B (CDTB). Methods: We retrospectively analysed the results for multiplex PCR, culture tests, and EIA obtained from stool specimens submitted to the laboratory from May 2013 to September 2014. Multiplex PCR was performed using the Seeplex diarrhea ACE detection kit (Seegene, Korea), which detects five viruses and eight bacteria.

Results: Among 890 stool specimens, 408 (45.8\%) were found to be positive by PCR. The PCR positivity rate for bacteria and viruses was 31.1\% (277/890) and 18.9\% (161/890), respectively. The relative frequencies of microorganisms or toxins detected by PCR were, in decreasing order, CDTB 24.0\%, Clostridium perfringens 20.6\%, norovirus-GII $15.8 \%$, rotavirus $11.3 \%$, Campylobacter spp. 7.5\%, enteric adenovirus 5.7\%, and Salmonella spp. $5.1 \%$. The concordance rate of the results obtained using the PCR and culture tests was 99.2\% for Salmonella spp., 95.7\% for Campylobacter spp., and. $79.8 \%$ for C. difficile. The concordance rates for rotaviruses and CDTB were $99.7 \%$ and $83.6 \%$, respectively.

Conclusions: The multiplex PCR method showed a high detection rate and is useful for the simultaneous detection of various diarrheal pathogens.

(J Lab Med Qual Assur 2015;37:141-147)

Key Words: Diarrhea, Multiplex polymerase chain reaction, Culture, Immunoenzyme techniques

Received March 26, 2015, Revision received July 26, 2015, Accepted July 27, 2015

\section{서론}

급성설사질환은 세계적으로 매년 높은 발생률을 보이는 감 염성 질환으로 5 세 미만 소아의 사망 원인으로 폐렴에 이어 두 번째를 차지한다[1]. World Health Organization와 United Nations Children's Fund 보고에 따르면 전 세계적으로 매년 2 억 건의 설사질환이 발생하고, 개발도상국에서는 190 만 명의 5 세 미만 어린이가 매년 설사로 인하여 사망한다[1]. 급성 감 염성 설사의 원인은 세균, 바이러스, 원충 등으로 매우 다양하 다. 그러나 검사방법과 비용의 제한 때문에 Salmonella spp.
와 Shigella spp.를 기본적으로 배양하고, 나라와 지역의 사정 에 따라 Vibrio spp., Escherichia coli O157, Campylobacter jejuni 등과 같은 병독력이나 유병률이 높은 몇 가지 원인 세균 만을 선별적으로 배양하며, 일부 바이러스에 대해서만 면역학 적 방법으로 검사하여 보고하여 왔다[2]. 최근 들어 다중중합 효소연쇄반응(multiplex PCR)을 이용한 대변 검체에서의 세 균과 바이러스의 동시 검출은 세균과 함께 감염성 설사의 주 요 원인인 바이러스에 대한 검출을 가능하게 하였다[2,3]. 이 번 연구에서는 세균과 바이러스 다중중합효소연쇄반응검사 에 의해 검출되는 설사 원인 병원체의 빈도를 조사하고, 다중 


\title{
Journal of LABORATORY MEDICINE and QUALITY ASSURANCE
}

\author{
Jeumsoon Lee et al • Stool Pathogen Detection by Multiplex PCR
}

중합효소연쇄반응의 세균성 병원체 검출은 통상적인 세균 배 양법과의 일치율을 비교하였으며, 다중중합효소연쇄반응의 Clostridium difficile toxin B (CDTB)와 rotavirus 검출은 효 소면역법과의 일치율을 분석하였다.

\section{재료 및 방법}

\section{1. 대상}

2013년 5월부터 2014년 9월까지 원주세브란스기독병원에 서 다중중합효소연쇄반응검사가 의뢰되었던 890개의 변 검 체 결과를 분석대상으로 하였으며, 연령별 분포는 5 세 이하 가 270명(30.3\%), 6-18세 145명(16.3\%), 19세 이상은 475 명 $(53.4 \%)$ 이었다. 다중중합효소연쇄반응검사와 대변 배양 결과의 일치율은 두 검사가 동시에 의뢰된 617검체를 대상 으로 분석하였고, 다중중합효소연쇄반응검사의 $\mathrm{CDTB}$ 와 $C$. difficile 배양의 일치율은 두 검사를 동시에 의뢰한 342검체를 대상으로 분석하였다. 다중중합효소연쇄반응검사의 $\mathrm{CDTB}$ 와 rotavirus의 효소면역법과의 일치율은 각각 342검체와 289검 체를 대상으로 비교하였다.

\section{2. 다중중합효소연쇄반응검사}

대변 검체에서 $\mathrm{DNA}$ 와 RNA의 추출은 Ribospin vRD (Gene All Biotechnology, Seoul, Korea)을 이용하였고, cDNA 합성 은 RevertAid First strand cDNA synthesis kit (Fermentas, Ontario, Canada)를 사용하여 제조회사의 지침에 따라 시 행하였다. 다중중합효소연쇄반응은 Seeplex Diarrhea ACE detection kit (Seegene, Seoul, Korea)를 이용하여 제조사 의 권고방법에 따라 시행하였다. PCR 증폭산물은 MultiNAautomatic electrophoresis system (Shimadzu, Kyoto, Japan)을 이용하여 전기영동한 후 kit 내에 포함된 양성 및 음 성 대조를 확인하고 결과를 해석하였다. 다중중합효소연쇄반 응검사에서 검출하는 세균 또는 세균 독소는 Aeromonas spp. (A. salmonicida, A. sobria, A. hydrophila), Campylobacter spp. (C. jejuni, C. coli), CDTB, Clostridium perfringens, verocytotoxin producing Escherichia coli O157:H7, Salmonella spp. (S. bongori, S. enteritica), Shigella spp. (S. flexneri, S. boydii, S. sonnei, S. dysenteriae), Vibrio spp. (V. cholerae, $V$. parahamolyticus, $V$. vulnificus)와 Yersinia enterocolitica의 9종류이고, 바이러스는 astrovirus, enteric adenovirus, norovirus GI, norovirus GII와 group A rotavirus의 5 종류이었다.

\section{3. 대변 배양}

대변 배양은 통상적인 방법에 따라 MacConkey 우무배 지, Salmonella-Shigella 우무배지, thiosulfate citrate bile sucrose (TCBS) 우무배지에 접종하여 $35^{\circ} \mathrm{C}$ 에서 24시간 배 양한 후에 관찰하였다. TCBS 우무배지는 매년 5월부터 11월 까지만 사용하였다. Selenite 액체 배지는 접종 24시간 후에 xylose-lysine-desoxycholate (Becton Dickinson, Sparks, $\mathrm{MD}, \mathrm{USA}$ ) 우무배지에 접종하고 Campylobacter 분리를 위해서는 CAMP-BAP 선택배지(Becton Dickinson)에 접 종하여 미호기성 조건으로 $42^{\circ} \mathrm{C}$ 에서 2 일간 배양하였다. $C$. difficile 배양검사가 의뢰된 검체는 chromID C. difficile 선 택배지(bioMerieux SA, Craponne, France)에 접종하여 $37^{\circ} \mathrm{C}$ 에서 24 시간 배양하였다. 균 동정은 생화학 성상을 토대 로 MicroScan WalkAway System (Siemens Healthcare, Erlangen, Germany)과 VITEK 2 system (BioMerieux, Marcy l'Etoile, France)을 이용하였다.

\section{Rotavirus 효소면역법}

대변의 효소면역법에 의한 rotavirus 검출은 ELISA (RIDASCREEN Rotavirus; Biopharm GmbH, Darmstadt, Germany)를 이용하여 제조회사의 권고방법에 따라 시행 한 후 PR 5100 ELISA plate reader (Biorad, Marnes-laCoquette, France)로 흡광도를 측정하였다.

\section{결과}

다중중합효소연쇄반응검사에서 양성을 보인 검체의 비 율은 45.8\% (408/890)였고, 한 가지 병원체와 두 가지 이상 의 병원체가 검출된 검체의 비율은 각각 $36.5 \%$ (325/890) 와 $9.3 \%$ (83/890)였다. 한 가지의 세균과 바이러스만 검출 된 검체의 비율은 각각 $23.4 \%$ (208/890)와 $13.1 \%$ (117/890) 였고, 두 종류 이상의 병원체가 검출된 검체에서 모두 세균 인 비율은 $4.4 \%$, 세균과 바이러스가 동시에 검출된 비율은 $3.4 \%$, 모두 바이러스만 검출된 비율은 $1.5 \%$ 였다. 연령대별 양성률은 5세 이하와 6-18세 사이가 각각 56.7\% (153/270) 와 57.9\% (84/145)로 비슷하였고, 19세 이상에서는 36.0\% (171/475)였다. 5세 이하에서 한 가지의 병원체만 검출된 비율 은 rotavirus, norovirus-GII, enteric adenovirus의 순으로 각 각 $10.4 \%, 9.3 \%$ 및 $5.2 \%$ 였으며, 2 개 이상의 병원체가 검출된 검체를 모두 포함하면 바이러스 양성률은 38.5\% (104/270) 이었고 세균 검출 양성률은 $25.2 \%$ (68/270)였다. 6-18세 연 령군에서 한 가지 병원체만 검출된 비율은 norovirus-GII가 
$9.0 \%$ 로 가장 높았고 Campylobacter spp.와 C. perfringens 가 $8.3 \%$ 로 동일하였으며 $\mathrm{CDTB}$ 는 $6.2 \%$ 였고, 2 개 이상의 병 원체가 검출된 검체를 모두 포함한 세균과 바이러스의 검체 양성률은 각각 41.4\% (60/145)와 22.8\% (33/145)였다. 19 세 이상에서는 CDTB, C. perfringens가 $12.8 \%$ 와 $8.2 \%$ 였고, 세균과 바이러스의 검출 양성률은 각각 $31.4 \%$ (149/475)와 4.8\% (23/475)였다(Table 1).

890검체에서 검출된 전체 병원체 수는 495 개로 세균/독 소는 64.2\% (318/495)였고 바이러스는 35.8\% (177/495) 였으며, 원인별로 상대적인 검출 비율은 CDTB $24.0 \%, C$. perfringens 20.6\%, norovirus-GII 15.8\% 및 rotavirus $11.3 \%$ 의 순이었다(Table 2). 대변 배양에서 균이 분리된 경 우에 PCR과 대변 배양의 결과 일치율은 Salmonella spp., Campylobacter spp.와 C. difficile의 순으로 $99.2 \%, 95.7 \%$ 및 $79.8 \%$ 였다. PCR과 대변 효소면역법과의 rotavirus와 $\mathrm{CDTB}$ 의 결과 일치율은 각각 $99.7 \%$ 와 $83.6 \%$ 였다(Table 3 ).

\section{고찰}

급성 세균성 설사의 원인은 지역사회 획득 감염과 병원 내 획득 감염으로 구분할 수 있다. 지역사회에서 획득한 세균성 설사질환은 대부분이 분변-구강 경로에 의해 감염되므로 공중 보건위생과 사회경제적 수준에 의해 유병률이 달라진다. 또한 국제적으로 인적 및 물적 교류가 활발하게 신속히 진행되고 기 후와 환경이 변화되며, 감염이 쉽게 될 수 있는 고연령층의 증 가, 식재료와 식생활의 변화 등은 새로운 설사 병원체의 출현 을 초래하게 된다[4]. 병원 내에서 획득한 세균성 설사질환은 주로 항균제나 항암제 투여 또는 방사선조사 등에 의해 발생하 며[1], 노령 환자와 면역기능저하 환자의 증가에 따라 발생률 이 높아지게 된다. 바이러스 설사질환은 rotavirus, norovirus, adenovirus와 astrovirus의 4가지가 주요 원인으로 돌발유행 (outbreak)에 따라 검출 빈도가 달라진다[4-6].

세균이나 바이러스의 감염을 진단하는 표준화 검사실 방법 은 배양 후 병원체를 확인하는 방법이다[7,8]. 이러한 방법들

Table 1. Detection rate of pathogenic microorganisms or toxins causing diarrhea by multiplex PCR in 890 stool specimens

\begin{tabular}{|c|c|c|c|c|}
\hline \multirow{2}{*}{ Microorganisms or toxins } & \multicolumn{4}{|c|}{$\begin{array}{c}\text { No. (\%) of positive samples as determined using PCR } \\
\text { according to age group (yr) }\end{array}$} \\
\hline & $0-5(n=270)$ & $6-18(n=145)$ & $\geq 19(n=475)$ & Total $(n=890)$ \\
\hline \multicolumn{5}{|l|}{ Bacteria } \\
\hline Aeromonas spp. (A. salmonicida, A. sobria, A. hydrophila) & $2(0.7)$ & $2(1.4)$ & $4(0.8)$ & $8(0.9)$ \\
\hline Clostridium perfringens & $10(3.7)$ & $12(8.3)$ & $39(8.2)$ & $61(6.9)$ \\
\hline Escherichia coli O157:H7, verocytotoxin producing & 0 & 0 & $2(0.4)$ & $2(0.2)$ \\
\hline Salmonella spp. (S. bongori, S. enteritica) & $6(2.2)$ & $4(2.8)$ & $6(1.3)$ & $16(1.8)$ \\
\hline Shigella spp. (S. flexneri, S. boydii, S. sonnei, S. dysenteriae) & 0 & 0 & $2(0.4)$ & $2(0.2)$ \\
\hline \multicolumn{5}{|l|}{ Viruses } \\
\hline Astrovirus & $7(2.6)$ & 0 & $1(0.2)$ & $8(0.9)$ \\
\hline Enteric adenovirus & $14(5.2)$ & $2(1.4)$ & $7(1.5)$ & $23(2.6)$ \\
\hline Norovirus GII & $25(9.3)$ & $13(9.0)$ & $11(2.3)$ & $49(5.5)$ \\
\hline Rotavirus & $28(10.4)$ & $7(4.9)$ & $2(0.4)$ & $37(4.1)$ \\
\hline \multicolumn{5}{|l|}{ Combined } \\
\hline Bacteria+bacteria & $11(4.1)$ & $9(6.2)$ & $19(4.0)$ & $39(4.4)$ \\
\hline Virus+virus & $11(4.1)$ & $2(1.4)$ & $1(0.2)$ & $14(1.5)$ \\
\hline Bacteria+virus & $19(7.0)$ & $10(6.9)$ & $1(0.2)$ & $30(3.4)$ \\
\hline
\end{tabular}




\section{Journal of LABORATORY MEDICINE and QUALITY ASSURANCE}

Jeumsoon Lee et al $\bullet$ Stool Pathogen Detection by Multiplex PCR

Table 2. Detection frequencies of bacteria and viruses by PCR

\begin{tabular}{|c|c|c|c|}
\hline Microorganisms or toxins & No. of positive samples & Total \% $(\mathrm{n}=890)$ & Relative \% $(\mathrm{n}=495)$ \\
\hline \multicolumn{4}{|l|}{ Bacteria } \\
\hline Aeromonas spp. (A. salmonicida, A. sobria, A. hydrophila) & 21 & 2.4 & 4.2 \\
\hline Campylobacter spp. (C. jejuni, C. coli) & 37 & 4.2 & 7.5 \\
\hline Clostridium difficile toxin B & 119 & 13.4 & 24.0 \\
\hline Clostridium perfringens & 102 & 11.5 & 20.6 \\
\hline Escherichia coli O157:H7, verocytotoxin producing & 2 & 0.2 & 0.4 \\
\hline Salmonella spp. (S. bongori, S. enteritica) & 25 & 2.8 & 5.1 \\
\hline Shigella spp. (S. flexneri, S. boydii, S. sonnei, S. dysenteriae) & 2 & 0.2 & 0.4 \\
\hline Vibrio spp. (V. cholerae, V.parahaemolyticus, V. vulnificus) & 3 & 0.3 & 0.6 \\
\hline Yersinia enterocolitica & 7 & 0.8 & 1.4 \\
\hline \multicolumn{4}{|l|}{ Viruses } \\
\hline Astrovirus & 14 & 1.6 & 2.8 \\
\hline Enteric adenovirus & 28 & 3.1 & 5.7 \\
\hline Norovirus GI & 1 & 0.1 & 0.2 \\
\hline Norovirus GII & 78 & 8.8 & 15.8 \\
\hline Rotavirus & 56 & 6.3 & 11.3 \\
\hline Total & 495 & 55.6 & 100.0 \\
\hline
\end{tabular}

Table 3. Comparison of the results of PCR with those of the culture tests and EIAs

\begin{tabular}{|c|c|c|c|c|c|c|c|c|c|}
\hline \multirow[b]{2}{*}{ Microorganisms or toxins } & \multicolumn{8}{|c|}{ No. of samples showing positivity using the different detection methods } & \multirow[b]{2}{*}{ Total } \\
\hline & $\begin{array}{c}\text { Culture+ } \\
\text { and } \\
\text { PCR+ }\end{array}$ & $\begin{array}{c}\text { Culture+ } \\
\text { and } \\
\text { PCR- }\end{array}$ & $\begin{array}{l}\text { Culture- } \\
\text { and } \\
\text { PCR+ }\end{array}$ & $\begin{array}{l}\text { Culture- } \\
\text { and } \\
\text { PCR- }\end{array}$ & $\begin{array}{c}\text { EIA+ } \\
\text { and } \\
\text { PCR+ }\end{array}$ & $\begin{array}{c}\text { EIA+ } \\
\text { and } \\
\text { PCR- }\end{array}$ & $\begin{array}{l}\text { EIA- } \\
\text { and } \\
\text { PCR+ }\end{array}$ & $\begin{array}{l}\text { EIA- } \\
\text { and } \\
\text { PCR- }\end{array}$ & \\
\hline \multicolumn{10}{|l|}{ Bacteria } \\
\hline Campylobacter spp. & 3 & 0 & 26 & 588 & & & & & 617 \\
\hline $\begin{array}{l}\text { Escherichia coli O157:H7, } \\
\text { verocytotoxin producing }\end{array}$ & 0 & 0 & 0 & 617 & & & & & 617 \\
\hline Salmonella spp. & 15 & 0 & 5 & 597 & & & & & 617 \\
\hline Shigella spp. & 0 & 0 & 2 & 614 & & & & & 617 \\
\hline Vibrio spp. & 0 & 0 & 3 & 614 & & & & & 617 \\
\hline Yersinia enterocolitica & 0 & 0 & 7 & 610 & & & & & 617 \\
\hline Clostridium difficile toxin B & 23 & 0 & 69 & 250 & 36 & 0 & 56 & 250 & 342 \\
\hline \multicolumn{10}{|l|}{ Viruses } \\
\hline Rotavirus & & & & & 49 & 1 & 0 & 239 & 289 \\
\hline
\end{tabular}

Abbreviations: EIA, enzyme immunoassay; +, positive; -, negative.

은 낮은 균 수로도 감염을 유발할 수 있는 병원체와 배양방법 으로는 증식이 어렵거나 느리게 성장하는 설사 원인 병원체 의 검출에는 위음성 결과를 초래할 수 있으며, 감염원의 보고 시간도 오래 걸리는 문제점이 있다[7,9]. 국내에서도 최근 이 러한 문제점을 보완할 수 있는 다중중합효소연쇄반응 검사가
도입되어 사용되고 있다[2,3]. 이번 연구에서의 다중중합효 소연쇄반응 검사에 의한 양성률은 $45.8 \%$ 로서 2010년 11월부 터 2011년 2월까지 Lee 등[2]이 이번 연구와 동일한 다중중합 효소연쇄반응 제품으로 평가하여 보고한 $34.1 \%$ 보다 높았다. Cho 등[3]은 2009년 6월부터 9월까지 다중중합효소연쇄반응 
법의 세균성 원인의 양성률은 $20.8 \%$ 로 보고하였는데 이는 이 번 연구의 $31.1 \%$ 보다 낮았다. 이번 결과가 다른 연구자에 비 해 높은 원인은 알 수 없으나 환자 분포의 특성 또는 다중중합 효소연쇄반응 결과를 판독할 때 비특이적인 전기영동 산물을 확인하기가 어려워 위양성 보고의 가능성이 있다.

$\mathrm{CDTB}$ 는 연령이 증가할수록 검출률이 높아져 성인에서는 $12.8 \%$, 전체 대상군에서는 $9.3 \%$ 로 미국에서 보고한 의료관 련감염의 $12.1 \%$ 와 유사하였다[10]. 최근 보고에 의하면 지 역사회에서 획득한 C. difficile 감염이 2005년부터 증가하기 시작하여 전체 C. difficile 감염의 $1 / 3$ 정도를 차지한다[11]. 지역사회 획득 $C$. difficile 감염의 빈도가 증가하는 것이 $C$. difficile 감염의 예방, 진단과 치료에 대한 지침을 임상 적용하 고 있음에도 불구하고 지속적으로 증가하는 원인의 하나로 생 각된다. Rotavirus와 norovirus-GII에 의한 설사는 대부분 영 유아에서 겨울철에 많이 발생하는 것으로 알려져 있으나 전 연 령층에서 감염을 일으킬 수 있으며, 최근에는 계절에 상관없이 집단발생의 경향을 보이기도 한다[12,13]. 질병관리본부에서 2012년부터 2013년까지 국내에서 발생한 norovirus 집단발생 을 분석한 결과에 의하면 2012 Sydney variant (GII-4변이주) 가 보고된 이래로 2012-2013년 동절기에 그 발생률이 매우 높 았으며, 기온이 비교적 따뜻하고 사람의 이동이 많은 봄철에는 GII보다는 GI이 많았음을 보고하였다[14]. 이번 조사 연구에 서는 norovirus GI은 없고 모두가 GII였는데 Lee 등[2]이 지 역이 서로 다른 6 개의 대학부속병원을 대상으로 한 연구결과 에서도 GI은 검출되지 않았다. 이번 연구와 제조사가 다른 중 합효소연쇄반응 kit로 2012년과 2013년 사이에 서울의 6개 병 원을 대상으로 한 연구에서는 norovirus GI과 GII의 검출 비 율은 각각 $5.6 \%$ 와 $94.4 \%$ 였다[15].

중합효소연쇄반응검사의 중복 검출률은 양성 검체의 $20.3 \%$ 로 Lee 등[2]의 $23.2 \%$ 와 비슷하였고, CDTB, C. perfringens, norovirus-GII, rotavirus 등과 같이 소아와 성인에 있어서 가 장 많은 빈도로 검출되는 균이나 바이러스에서 중복 검출되 는 빈도가 높았다. 중합효소연쇄반응검사와 동시에 의뢰된 배양결과에서 배양 양성이었으나 중합효소연쇄반응검사에 서 음성인 경우는 없었고, Campylobacter spp.는 배양에서 3 균주 $(0.5 \%)$ 만이 검출되었으나 중합효소연쇄반응검사에서는 29개(4.7\%)가 양성이었고 Shigella spp., Vibrio spp.와 Y. enterocolitica는 배양에서 분리되지 않았으나 중합효소연쇄 반응검사에서는 각각 2 검체, 3 검체 및 7검체에서 양성이었다. Shigella spp.가 양성이었던 DNA 추출물은 제조회사에 염기 서열분석을 의뢰하였으나 Shigella sonnei와 E. coli의 유전자 상동성이 모두 $100 \%$ 로 균종을 확인할 수 없었다.
다중중합효소연쇄반응검사는 민감도가 매우 높고 위양성도 낮은 것으로 판단되나 몇 가지 개선이 필요할 것으로 생각되었 다. 세균성 설사질환 중 제 1 군법정감염병에 속하는 콜레라, 장 티푸스, 세균성이질은 균종 수준까지 동정해야 한다. 다중중합 효소연쇄반응은 Vibrio, Salmonella와 Shigella를 균속 수준 에서 검출하므로 양성결과의 임상적 의의를 해석하기 어려운 제한점이 있다. C. perfringens는 설사를 유발하기 위해서는 $10^{9-10}$ 개의 집락수가 필요하므로[16] C. perfringens의 존재 유 무만을 확인할 수 있는 cpa 유전자를 검출하는 중합효소연쇄 반응검사로는 설사 원인으로서의 임상적 의의를 평가하기 어 렵다[1,3]. C. perfringens에 의한 설사질환은 미국에서 두 번 째로 흔한 식중독의 원인으로 식중독 돌발 발생의 진단을 위해 서는 두 명 이상의 설사 변에서 $10^{6}$ 이상의 C. perfringens가 분리되거나 enterotoxin이 검출되어야 한다[17]. 다중중합효 소연쇄반응검사에 C. perfringens의 enterotoxin인 cpe 유전 자를 검출하는 방법의 개선이 필요할 것으로 생각되었다.

본 연구의 제한점으로는 후향적으로 자료를 분석하였기에 환자의 임상적 특성과 연관하여 분석할 수 없었고, 다중중합효 소연쇄반응검사와 배양검사가 동시에 의뢰된 경우에 한하여 결과를 비교했기 때문에 두 검사법의 일치율 평가에 오류의 가 능성이 있었다.

\section{REFERENCES}

1. Farthing M, Salam MA, Lindberg G, Dite P, Khalif I, Salazar-Lindo E, et al. Acute diarrhea in adults and children: a global perspective. J Clin Gastroenterol 2013;47:12-20.

2. Lee S, Park YJ, Lee HK, Kim SY, Kim JY, Lee SY, et al. Detection of 13 enteric bacteria and 5 viruses causing acute infectious diarrhea using multiplex PCR from direct stool specimens. Ann Clin Microbiol 2013;16:33-8.

3. Cho MC, Noh SA, Kim MN, Kim KM. Direct application of multiplex PCR on stool specimens for detection of enteropathogenic bacteria. Korean J Clin Microbiol 2010;13:162-8.

4. Jones TF, Keene WE. Investigation of enteric disease outbreaks. In: Versalovic J, Carroll KC, Funke G, Jorgensen JH, Landry ML, editors. Manual of clinical microbiology. 10th ed. Washington (DC); ASM Press, 2011:85-99.

5. National Institutes of Health. Viral gastroenteritis. http:// 


\section{Journal of LABORATORY MEDICINE and QUALITY ASSURANCE}

Jeumsoon Lee et al • Stool Pathogen Detection by Multiplex PCR

www.niddk.nih.gov/health-information/health-topics/ digestive-diseases/viral-gastroenteritis/Documents/ Viral_Gastroenteritis_508.pdf (Accessed March 21, 2015).

6. Hall AJ, Wikswo ME, Manikonda K, Roberts VA, Yoder JS, Gould LH. Acute gastroenteritis surveillance through the National Outbreak Reporting System, United States. Emerg Infect Dis 2013;19:1305-9.

7. Fan H, Wu Q, Kou X. Co-detection of five species of water-borne bacteria by multiplex PCR. Life Sci J 2008;5:47-54.

8. Khamrin P, Okame M, Thongprachum A, Nantachit N, Nishimura S, Okitsu S, et al. A single-tube multiplex PCR for rapid detection in feces of 10 viruses causing diarrhea. J Virol Methods 2011;173:390-3.

9. Rahman I, Shahamat M, Chowdhury MA, Colwell RR. Potential virulence of viable but nonculturable Shigella dysenteriae type 1. Appl Environ Microbiol 1996;62:11520.

10. Magill SS, Edwards JR, Bamberg W, Beldavs ZG, Dumyati G, Kainer MA, et al. Multistate point-prevalence survey of health care-associated infections. N Engl J Med 2014;370:1198-208.

11. Chitnis AS, Holzbauer SM, Belflower RM, Winston LG, Bamberg WM, Lyons C, et al. Epidemiology of community-associated Clostridium difficile infection, 2009 through 2011. JAMA Intern Med 2013;173:1359-67.

12. Payne DC, Vinje J, Szilagyi PG, Edwards KM, Staat MA, Weinberg GA, et al. Norovirus and medically attended gastroenteritis in U.S. children. N Engl J Med 2013;368:1121-30.

13. Moon SK, Lee JI, Yoon HS, Ahn YM. Isolation rate of 4 type virus of acute gastroenteritis in full-term neonates during neonatal period. Korean J Pediatr 2007;50:855-61.

14. Chung SY, Lee DY. Molecular epidemiology of norovirusrelated outbreaks in Korea, 2012-2013. KCDC PHWR 2014;7:1157-61.

15. Ham H, Oh S, Seung H, Jo S. Molecular characteristics of noroviruses genogroup I and genogroup II detected in patients with acute gastroenteritis. Ann Lab Med 2015;35:242-5.

16. Gilligan PH, Janda JM, Karmali MA, Miller JM. Cumitech 12A. In: Gilligan PH, Nolte FS, editors. Laboratory diagnosis of bacterial diarrhea. Coordinating ed. Washington (DC): American Society for Microbiology, 1992.

17. Grass JE, Gould LH, Mahon BE. Epidemiology of foodborne disease outbreaks caused by Clostridium perfringens, United States, 1998-2010. Foodborne Pathog Dis 2013;10:131-6. 
대변 검체에서 다중중합효소연쇄반응에 의한 세균과 바이러스 병원체의 검출

\section{이점순 • 김주원 • 조현미 • 오기진 • 어 영 • 윤갑준}

연세대학교 원주의과대학 원주세브란스기독병원 진단검사의학교실

배경: 설사 병원체의 신속하고 정확한 검출은 설사질환의 전파 방지에 매우 중요하다. 최근 다양한 세 균과 바이러스 설사 병원체를 동시에 검출할 수 있는 다중중합효소연쇄반응이 개발되었고, 이번 연구 에서는 다중중합효소연쇄반응에서 검출되는 설사 병원체의 검출 빈도를 조사하였으며, 더불어 세균 배양과 rotavirus와 Clostridium difficile toxin B (CDTB)에 대한 효소면역법 결과와 비교하였다.

방법: 2013년 5월부터 2014년 9월까지 대변 검체에서 시행한 다중중합효소연쇄반응, 배양 및 효소 면역법 결과를 후향적으로 분석하였다. 다중중합효소연쇄반응은 5 종류의 바이러스와 8 종류의 세균 을 검출할 수 있는 Seeplex diarrhea ACE detection kit를 사용하였다.

결과: 890 대변 검체에서 408검체(45.8\%)가 중합효소연쇄반응에서 양성이었고 세균과 바이러 스 양성 검체의 비율은 각각 31.1\% (277/890)와 18.9\% (161/890)였다. 중합효소연쇄반응에서 검출된 미생물이나 독소의 상대적 검출 비율은 CDTB 24.0\%, Clostridium perfringens $20.6 \%$, Norovirus-GII 15.8\%, rotavirus 11.3\%, Campylobacter spp. 7.5\%, enteric adenovirus $5.7 \%$ 와 Salmonella spp. 5.1\%의 순이었다. 중합효소연쇄반응과 배양 일치율은 Salmonella spp. 99.2\%, Campylobacter spp. 95.7\% 및 C. difficile 79.8\%였다. 중합효소연쇄반응과 효소면역법 의 일치율은 rotavirus와 CDTB가 각각 $99.7 \%$ 와 $83.6 \%$ 였다.

결론: 설사 원인균 검출법인 다중중합효소연쇄반응 검사는 검출률이 높고 다양한 병원체를 동시에 검 출하는 데 유용하였다.

(J Lab Med Qual Assur 2015;37:141-147) 